\title{
Psychosocial Care Centers and the profile of pervasive developmental disorder cases in Brazil, 2014-2017
}

\author{
| ${ }^{1}$ Jeane Tomazelli, ${ }^{2}$ Conceição Fernandes |
}

Abstract: The study describes the profile of children and adolescents with pervasive developmental disorders (PDD) attended at the Psychosocial Care Centers (CAPS) and professionals from these establishments in Brazil and regions. It uses data from the Outpatient Information System of the Unified Health System (SIA/SUS) and the National System of Health Establishments System (SCNES) in 2014-2017. The SIA/SUS was deterministically linked with the SCNES, based on the establishment number. PDD cases were individualized using a variable coded SUS card; 18,852 diagnoses of PDD were recorded in CAPS, most of them by spontaneous demand, $73.2 \%$ performed in CAPSi, $50.3 \%$ in the age group of $1-6$ years old, $80 \%$ male and highest proportions of females over 13 years ( $\mathrm{p}<0.001$ ). PDD was not specified in $54.3 \%$ of the diagnoses; autistic disorder was the most common PDD (27.2\%). Professional teams vary by CAPS type; Procedures of communicative practices and psychosocial rehabilitation were not expressive (10.3\%). It was concluded that studies are necessary to clarify a high spontaneous demand, to understand treatment outside CAPSi and to define parameters to evaluate if the procedures used are appropriated for the therapeutic project and possibilities monitoring and evaluate the care of people with PDD.

Keywords: Developmental Disabilities; Autism Spectrum Disorder; Mental Health Services; Unified Health System; Epidemiology, Descriptive.

\author{
1 Instituto Nacional do Câncer. Rio \\ de Janeiro-RJ, Brasil (dra.jeane. \\ tomazelli@gmail.com). \\ ORCID: 0000-0002-2472-3444 \\ ${ }^{2}$ Pontifícia Universidade Católica \\ do Rio de Janeiro. Rio de Janeiro \\ -RJ, Brasil (conceicaosf@yahoo. \\ com.br). \\ ORCID: 0000-0003-2570-0655
}

Recebido em: 18/07/2019 Aprovado em: 16/12/2019 Revisado em: 19/05/2021 


\section{Introduction}

Neuropsychiatric disorders are the main source of disease burden among chronic non-communicable diseases (SCHMIDT et al., 2011). In children, child neurodevelopmental impairments are the most frequent neurological disorder, with rates between 60-70 per 10,000 (FOMBONNE, 2009).

In Brazil, the International Statistical Classification of Diseases and Related Health Problems (ICD) is the classification system adopted in the Unified Health System (SUS) and uses the terminology "pervasive developmental disorder" (PDD) to refer to neurodevelopmental disorders (WHO, 1996). On the other hand, the scientific community is currently adopting "autism spectrum disorder" (ASD) to designate three more similar PDD conditions, which were incorporated into the DSM-5 (FERREIRA, 2013) and, recently, in the ICD-XI (WHO, 2018): autistic disorder, Asperger's syndrome and PDD / invasive developmental disorder with no other specification (PAULA et al., 2017; LYRA et al., 2017). The DSM-5 incorporated the ASD to the group of neurodevelopmental disorders in which, in addition to the delay or interruption of the normal development process, it has also an atypical and harmful clinical manifestation, affecting a set of psychic functions (BRASIL, 2014a).

Considering that the diagnosis of ASD occurs at the beginning of child development and lasts a lifetime (PAULA et al., 2011a; YANG et al., 2018), an accurate, early diagnosis and guaranteed access to therapies is extremely important to assist in the development of skills, ensuring autonomy and quality of life to the individual, within his possibilities. Therefore, estimating the disease burden of autistic and other disorders is fundamental to direct public health policies and actions that provide adequate interventions and support for these people (BAXTER et al., 2015).

However, estimating the prevalence of autism is a challenge, given the methodological differences of the studies, the eligibility criteria of cases (capture of cases with and without a previous warning sign), the standardization of instruments used according to specific populations and the definition of case study itself (FOMBONNE, 2018). The complexity of the accurate diagnosis and estimates of the occurrence of the disease was observed by Baxter, who found a difference in the prevalence estimates according to the source of the case data and the classification manual adopted, with a higher estimate of autistic disorder when using the ICD-10 or DSM-IV compared with previous versions (BAXTER et al., 2015). 
The expression of ASD symptoms can show great variability, and it is possible to identify children with low and high degree of functioning (KLIN, 2006). The diagnosis is eminently clinical (PAULA et al., 2017; TAMANAHA et al., 2013), made from behavioral aspects. Assessment must be carried out by a group of professionals with expertise in different areas, in order to favor a multidisciplinary understanding and more appropriate interventions (KLIN et al., 2005). The evaluation should include detailed anamnesis, psychological and developmental assessments, as well as measurement of adaptive skills. The assessment of verbal and non-verbal communication is especially important, with differentiation from language development disorder (KLIN, 2006). Neuropsychological assessment will be important in assessing intelligence - thus distinguishing intellectual deficit from ASD (PEDERSEN et al., 2017) - and in measuring the severity of symptoms in the spectrum, by identifying associated cognitive deficit and more severe levels of inattention. The accurate diagnosis also includes assessments of development, social interaction, communication and adaptive skills (KLIN, 2006).

Structured tools were developed to support the clinical diagnosis, assisting in the assessment of the diagnostic hypothesis and in the measurement of the degree of impairment (HAASE; JÚLIO-COSTA, 2018). Such instruments are considered important, given the variations in the clinical conditions, typical of the development, and previous treatments carried out, in addition to the diversity in the training of different professional categories that deal with these children in our country (PAULA et al., 2017) and, still, due to the existence of competing theoretical models (BRASIL, 2015; OLIVEIRA et al., 2017).

In the specialized care provided by the Unified Health System, individuals with PDD are treated at Psychosocial Care Centers (CAPS) and at the Psychosocial Care Network (RAPS) points (BRASIL, 2014a; 2015; 2011). This network aims to create, expand and articulate points of health care for people with some type of mental disorder and needs arising from drug use, in addition to monitoring and evaluating the quality of services through indicators of effectiveness and problem-solving care. Among its guidelines are the guarantee of access and quality of services, with comprehensive and multidisciplinary care. Social rehabilitation and the reintegration of individuals with mental disorders or needs resulting from alcohol abuse or other drugs are some of its specific objectives (BRASIL, 2014a; 2011). 
CAPS have three modalities, CAPS I, II and III, all with the same function in mental health care, but with differences in size / complexity, population coverage and working shifts (BRASIL, 2002). They are organized as follows (BRASIL, 2011): CAPS I, CAPS II, CAPS III, CAPS AD (alcohol and drugs), CAPS AD III and CAPSi (children and adolescents). CAPSi is the only one specifically for children and adolescents (BRASIL, 2011). With the exception of CAPSi, which admits cases up to the age of 25, and CAPS AD and CAPS AD III, which admit cases from the age of six, all CAPS can perform procedures on people aged 0 to 110 years (BRASIL, 2013).

In all CAPS, the multi-professional team has between three and five members, consisting of a doctor, a nurse and a group of other professionals with higher education who, depending on the type of CAPS, can be a psychologist, occupational therapist, social worker or another necessary for the therapeutic project (BRASIL, 2002). The Ministry of Health highlights that in the treatment of people with ASD, professionals and the reference team for care must preserve the subject's uniqueness, building and strengthening the bond with the patient and the family (BRASIL, 2014a). The multidisciplinary team is an important component in the evaluation and monitoring of ASD patients (KLIN et al., 2005; BRASIL, 2015; 2014b), which is fundamental to the therapeutic project, and must be composed, at least, by a psychiatrist and / or neurologist and / or pediatrician, psychologist and speech therapist (BRASIL, 2014b).

A study evaluating the use of health services by public school students with ASD in four Brazilian regions reported low use in consultations with a psychologist, neurologist and psychiatrist (PARASMO; LOWENTHAL; PAULA, 2015). Another study described the profile of CAPSi use by children and adolescents from 2008 to 1012, based on the procedures registered in the High Complexity Procedures Authorizations (APAC), analyzing the most frequent diagnoses, according to the ICD-10, sex and age (CEBALLOS et al., 2019). While the first study sought to identify the adhesion of students with ASD to specialized monitoring, the second traces the profile of children and adolescents treated in the only type of CAPS specific to them.

Considering that child neurodevelopmental impairment is a chronic disease, which requires early identification and specialized monitoring in order to provide the development of skills and autonomy (within individual possibilities), the existence of specialized care centers to assist people with this disorder and considering, also, 
the need for a team of specialized professionals, this study aimed to describe the profile of children and adolescents with pervasive developmental disorder attended at Psychosocial Care Centers and their care production, as well as the profile of professionals of these establishments in Brazil and regions, from 2014 to 2017.

\section{Methods}

This is a descriptive, ecological study, with secondary data from the information from the Outpatient Action Registry (RAAS) of the Outpatient Information System of the Unified Health System (SIA / SUS) and the National Registry of Health Facilities (SCNES), available on the SUS Informatics Department website (Datasus) (www.datasus.gov.br), from 2014 to 2017, for Brazil. The study period was defined considering that the procedures started to be launched at RAAS from 2013 (BRAZIL, 2013) and that 2017 was the last year available at the beginning of this study.

From SCNES, health establishments with the following qualification codes were selected: 0616 (CAPS 1), 0617 (CAPS II), 0618 (CAPS III), 0619 (CAPS AD), 0620 (CAPSI) and 0631 (CAPS AD III); and the number of professionals in the categories psychologist (clinical, social, neuropsychologist), speech therapist and occupational therapist. The selection of these professional categories was justified by the fact that they are part of the possible categories necessary to make up the therapeutic project together with a doctor and nurse (BRASIL, 2002). The number of professionals by type of qualification at CAPS was verified, per year in Brazil and regions.

From the SIA / SUS, the procedures performed were selected, whose main ICD10 reported was PDD (F84). Through the coded variable National Health Card (CNS), the cases attended in the period from 2014 to 2017 were individualized. The number of cases attended per year and by type of CAPS was then obtained.

The database with the information of the cases attended was deterministically related to the SCNES database, using the variable National Registry of Health Establishments (CNES) as the key relationship, thus producing a new database containing only the enabled services that reported care for people with PDD. Of these, a CAPS AD, from the Southeast region, reported a single case, in the age group 13-19 years, and was excluded from the results.

The following variables were studied: CNES of the health establishment, year of attendance (information generated from the date of attendance), age group, in 
years (less than 1; 1-6; 7-12; 13-19; and 20 or more), sex (male, female), race / color (white, black, brown, yellow, indigenous), diagnosis (obtained by the main ICD), origin of the patient (spontaneous demand, primary care, emergency service, other CAPS, day hospital, psychiatric hospital), procedures performed, state and region of residence, qualification of the health establishment (CAPS I; CAPS II; CAPS III; CAPSi; CAPS AD; CAPS AD III), state and region of the health establishment and professionals (psychologist - clinical, social, neuropsychologist; speech therapist; occupational therapist).

The information was evaluated and described comparatively between the regions of the country. The chi-square trend test (ROSNER, 2016) was applied to assess whether the difference in the proportion of the female age groups was significant.

The databases were downloaded in April 2018. The R program (R CORE TEAM, 2013) was used for data analysis. The study exempts itself from being submitted to the ethics committee for using secondary data with unrestricted access.

\section{Results}

From 2014 to 2017, there were 18,852 cases diagnosed with PDD treated at CAPS in Brazil. Most diagnoses occurred in the age group 1-6 years old (50.3\%), for males (80\%). In $54.3 \%$ of the cases, the ICD of the PDD type was not specified, and autistic disorder (27.2\%) was the most frequent type among those specified. The most frequent race / color was brown (31\%), followed by white (25.4\%). Regarding the patient's origin, the majority $(51.3 \%)$ had a spontaneous demand record at the Psychosocial Care Center, followed by referrals originating from primary care (43.2\%) - Table 1.

Table 1. Characteristics of cases with the main diagnosis of pervasive developmental disorder. Brazil, 2014-2017

\begin{tabular}{lcc}
\hline Variables & $\mathbf{n}$ & $\%$ \\
\hline Age group & & \\
$<1$ year & 236 & 1.3 \\
$1-6$ years & 9,486 & 50.3 \\
$7-12$ years & 5,397 & 28.6 \\
& & \\
& & to be continued...
\end{tabular}




\begin{tabular}{|c|c|c|}
\hline Variables & $\mathrm{n}$ & $\%$ \\
\hline $13-19$ years & 2,574 & 13.7 \\
\hline$>20$ years & 1,159 & 6.1 \\
\hline Total & 18,852 & 100.0 \\
\hline \multicolumn{3}{|l|}{ Sex } \\
\hline Female & 3,762 & 20.0 \\
\hline Male & 15,091 & 80.0 \\
\hline Total & 18,852 & 100.0 \\
\hline \multicolumn{3}{|l|}{ Race/color } \\
\hline White & 4,797 & 25.4 \\
\hline Black & 414 & 2.2 \\
\hline Brown & 5,842 & 31.0 \\
\hline Yellow & 537 & 2.8 \\
\hline Indigenous & 5 & 0.0 \\
\hline No information & 7.257 & 38.5 \\
\hline Total & 18,852 & 100.0 \\
\hline \multicolumn{3}{|l|}{ Patient's origin } \\
\hline Spontaneous demand & 9,663 & 51.3 \\
\hline Primary care & 8,142 & 43.2 \\
\hline Emergency service & 271 & 1.4 \\
\hline Other CAPs & 354 & 1.9 \\
\hline Day-hospital & 351 & 1.9 \\
\hline Psychiatric hospital & 71 & 0.4 \\
\hline Total & 18,852 & 100.0 \\
\hline \multicolumn{3}{|l|}{ Qualification of CAPS ${ }^{2}$} \\
\hline CAPS I & 3,091 & 16.4 \\
\hline CAPS II & 1,391 & 7.4 \\
\hline CAPS III & 358 & 1.9 \\
\hline CAPSi & 13,799 & 73.2 \\
\hline CAPS AD III & 213 & 1.1 \\
\hline Total & 18,852 & 100.0 \\
\hline
\end{tabular}




\begin{tabular}{|c|c|c|}
\hline Variables & $\mathbf{n}$ & $\%$ \\
\hline Variables & $\mathrm{n}$ & $\%$ \\
\hline \multicolumn{3}{|l|}{ First year at Psychosocial Care Center } \\
\hline 2014 & 3,724 & 19.8 \\
\hline 2015 & 4,049 & 21.5 \\
\hline 2016 & 4,945 & 26.2 \\
\hline 2017 & 6,134 & 32.5 \\
\hline Total & 18,852 & 100.0 \\
\hline \multicolumn{3}{|l|}{ Region of residence } \\
\hline Midwest & 613 & 3.3 \\
\hline Northeast & 5,149 & 27.3 \\
\hline North & 1,544 & 8.2 \\
\hline Southeast & 9,995 & 53.0 \\
\hline South & 1,551 & 8.2 \\
\hline Total & 18,852 & 100.0 \\
\hline \multicolumn{3}{|l|}{ Diagnoses } \\
\hline Pervasive development disorder (F84¹) & 10,231 & 54.3 \\
\hline autistic disorder (F840) & 5,124 & 27.2 \\
\hline Atypical autism (F841) & 722 & 3.8 \\
\hline Rett's syndrome (F842) & 61 & 0.3 \\
\hline Other disintegrative disorder (F843) & 157 & 0.8 \\
\hline $\begin{array}{l}\text { Overactive disorder associated with mental retardation } \\
\text { and stereotyped movements (F844) }\end{array}$ & 148 & 0.8 \\
\hline Asperger's syndrome (F845) & 771 & 4.1 \\
\hline Other pervasive development disorders (F848) & 432 & 2.3 \\
\hline Pervasive developmental disorders, unspecified (F849) & 1,206 & 6.4 \\
\hline Total & 18,852 & 100.0 \\
\hline
\end{tabular}

${ }^{1}$ Subcategory not specified. ${ }^{2}$ Excluded a single case reported in the CAPSad.

The total number of CAPS studied was 1,178, with 620 (52.6\%) CAPS I; 277 (23.5\%) CAPS II; 221 (18.8\%) CAPSi; 58 (4.9\%) CAPS III; and two (0.2\%) CAPS AD III. This pattern of proportional distribution was repeated between regions, 
except in the South, where the proportion of CAPSi (24.7\%) was greater than that of CAPS II (22.9\%), corresponding to 42 and 39 establishments, respectively. Comparing the distribution of the 221 CAPSi among the regions, the one with the highest proportion was the Southeast $(28.1 \%)$ and the smallest was the North (6.0\%), with 115 and 6 establishments each - data not shown.

The type of CAPS with the highest attendance of cases with PDD was CAPSi (73.2\%), followed by CAPS I (16.4\%), with an increase in the number of cases attended over the years of study. Of the 18,852 cases diagnosed with PDD, 13,799 were attended to in the $221 \mathrm{CAPSi}$, which corresponds to a ratio of 62 cases / CAPSi in the three-year period. The Southeast and Northeast regions recorded higher proportions of the number of cases, $53.0 \%$ and $27.3 \%$, respectively - Table 1 .

In the Brazil, CAPS I presented most cases (68\%) attended in the age group of 1-12 years, a similar scenario to those in the North, Northeast and Southeast regions. In CAPS II, the most frequent age group (40\%) was 20 years or more, the same pattern observed in other regions, except in the North. CAPSi presented more than half $(57.1 \%)$ of visits in the age group of $1-6$ years, a pattern followed by the regions of the country, except for the North and South. In the age group of 1-12 years, the proportion was $86.8 \%$ in the country, ranging from $85.1 \%$ in the Southeast to $90.9 \%$ in the Northeast. CAPS AD III presented a record of attendance to PDD cases only in the Southeast and South regions (Table 2).

Table 2. Distribution of cases with main diagnosis of pervasive developmental disorder by type of Psychosocial Care Center ${ }^{1}$ and age group, Brazil and large regions, 2014-2017

\begin{tabular}{|c|c|c|c|c|c|c|c|c|c|c|c|c|}
\hline \multirow{2}{*}{$\begin{array}{l}\text { Age group } \\
\text { (years) }\end{array}$} & \multicolumn{2}{|c|}{ Brazil } & \multicolumn{2}{|c|}{ Nortth } & \multicolumn{2}{|c|}{ Northeast } & \multicolumn{2}{|c|}{ Southeast } & \multicolumn{2}{|c|}{ Midwest } & \multicolumn{2}{|c|}{ South } \\
\hline & $\mathrm{n}$ & $\%$ & $\mathrm{n}$ & $\%$ & $\mathrm{n}$ & $\%$ & $\mathrm{n}$ & $\%$ & $\mathrm{n}$ & $\%$ & $\mathrm{n}$ & $\%$ \\
\hline & \multicolumn{12}{|c|}{ CAPS I } \\
\hline$<1$ & 29 & 0.9 & 1 & 0.3 & 17 & 1.1 & 9 & 1.2 & 1 & 1.3 & 1 & 0.4 \\
\hline $1-6$ & 1,133 & 36.7 & 131 & 38.3 & 639 & 39.5 & 274 & 35.0 & 20 & 26.7 & 69 & 25.0 \\
\hline $7-12$ & 969 & 31.3 & 103 & 30.1 & 517 & 32.0 & 241 & 30.8 & 24 & 32.0 & 84 & 30.4 \\
\hline $13-19$ & 537 & 17.4 & 65 & 19.0 & 251 & 15.5 & 132 & 16.9 & 20 & 26.7 & 69 & 25.0 \\
\hline$>20$ & 423 & 13.7 & 42 & 12.3 & 192 & 11.9 & 126 & 16.1 & 10 & 13.3 & 53 & 19.2 \\
\hline Total & 3,091 & 100.0 & 342 & 100.0 & 1.616 & 100.0 & 782 & 100.0 & 75 & 100.0 & 276 & 100.0 \\
\hline
\end{tabular}

to be continued... 


\begin{tabular}{|c|c|c|c|c|c|c|c|c|c|c|c|c|}
\hline \multirow{2}{*}{$\begin{array}{l}\text { Age group } \\
\text { (years) }\end{array}$} & \multicolumn{2}{|c|}{ Brazil } & \multicolumn{2}{|c|}{ Nortth } & \multicolumn{2}{|c|}{ Northeast } & \multicolumn{2}{|c|}{ Southeast } & \multicolumn{2}{|c|}{ Midwest } & \multicolumn{2}{|c|}{ South } \\
\hline & $\mathrm{n}$ & $\%$ & $\mathrm{n}$ & $\%$ & $\mathrm{n}$ & $\%$ & $\mathrm{n}$ & $\%$ & $\mathrm{n}$ & $\%$ & $\mathrm{n}$ & $\%$ \\
\hline & \multicolumn{12}{|c|}{ CAPS II } \\
\hline$<1$ & 17 & 1.2 & 2 & 1.3 & 4 & 1.2 & 10 & 1.3 & 0 & 0.0 & 1 & 1.0 \\
\hline $1-6$ & 280 & 20.1 & 62 & 40.5 & 95 & 28.3 & 112 & 14.7 & 2 & 5.0 & 9 & 9.0 \\
\hline $7-12$ & 197 & 14.2 & 38 & 24.8 & 47 & 14.0 & 91 & 11.9 & 9 & 22.5 & 12 & 12.0 \\
\hline $13-19$ & 329 & 23.7 & 22 & 14.4 & 90 & 26.8 & 183 & 24.0 & 10 & 25.0 & 24 & 24.0 \\
\hline$>20$ & 568 & 40.8 & 29 & 19.0 & 100 & 29.8 & 366 & 48.0 & 19 & 47.5 & 54 & 54.0 \\
\hline \multirow[t]{2}{*}{ Total } & 1,391 & 100.0 & 153 & 100.0 & 336 & 100.0 & 762 & 100.0 & 40 & 100.0 & 100 & 100.0 \\
\hline & \multicolumn{12}{|c|}{ CAPS III } \\
\hline$<1$ & 5 & 1.4 & 0 & 0.0 & 1 & 4.5 & 4 & 1.3 & 0 & 0.0 & 0 & 0.0 \\
\hline $1-6$ & 91 & 25.4 & 5 & 26.3 & 4 & 18.2 & 82 & 26.6 & 0 & 0.0 & 0 & 0.0 \\
\hline $7-12$ & 63 & 17.6 & 2 & 10.5 & 1 & 4.5 & 60 & 19.5 & 0 & 0.0 & 0 & 0.0 \\
\hline $13-19$ & 74 & 20.7 & 6 & 31.6 & 6 & 27.3 & 61 & 19.8 & 0 & 0.0 & 1 & 12.5 \\
\hline$>20$ & 125 & 34.9 & 6 & 31.6 & 10 & 45.5 & 101 & 32.8 & 1 & 100.0 & 7 & 87.5 \\
\hline \multirow[t]{2}{*}{ Total } & 358 & 100.0 & 19 & 100.0 & 22 & 100.0 & 308 & 100.0 & 1 & 100.0 & 8 & 100.0 \\
\hline & \multicolumn{12}{|c|}{ CAPSi } \\
\hline$<1$ & 183 & 1.3 & 10 & 1.0 & 45 & 1.4 & 114 & 1.4 & 6 & 1.2 & 8 & 0.7 \\
\hline $1-6$ & 7,877 & 57.1 & 502 & 48.7 & 2.044 & 64.4 & 4.540 & 56.6 & 275 & 55.3 & 516 & 47.8 \\
\hline $7-12$ & 4,105 & 29.7 & 398 & 38.6 & 842 & 26.5 & 2.285 & 28.5 & 166 & 33.4 & 414 & 38.4 \\
\hline $13-19$ & 1,592 & 11.5 & 120 & 11.7 & 239 & 7.5 & 1.045 & 13.0 & 50 & 10.1 & 138 & 12.8 \\
\hline$>20$ & 42 & 0.3 & 0 & 0.0 & 5 & 0.2 & 34 & 0.4 & 0 & 0.0 & 3 & 0.3 \\
\hline \multirow[t]{2}{*}{ Total } & 13,799 & 100 & 1.030 & 100 & 3.175 & 100 & 8.018 & 100 & 497 & 100 & 1.079 & 100 \\
\hline & \multicolumn{12}{|c|}{ CAPS AD III } \\
\hline$<1$ & 2 & 0.9 & 0 & 0.0 & 0 & 0.0 & 2 & 1.6 & 0 & 0.0 & 0 & 0.0 \\
\hline $1-6$ & 105 & 49.1 & 0 & 0.0 & 0 & 0.0 & 62 & 49.6 & 0 & 0.0 & 43 & 48.9 \\
\hline $7-12$ & 63 & 29.4 & 0 & 0.0 & 0 & 0.0 & 29 & 23.2 & 0 & 0.0 & 34 & 38.6 \\
\hline $13-19$ & 42 & 19.6 & 0 & 0.0 & 0 & 0.0 & 31 & 24.8 & 0 & 0.0 & 11 & 12.5 \\
\hline$>20$ & 1 & 0.5 & 0 & 0.0 & 0 & 0.0 & 1 & 0.8 & 0 & 0.0 & 0 & 0.0 \\
\hline Total & 213 & 99.5 & 0 & 0 & 0 & 0 & 125 & 100 & 0 & 0 & 88 & 100.0 \\
\hline
\end{tabular}

${ }^{1}$ Excluded a single case reported in the CAPS AD. 
The proportion of diagnoses of PDD was around $80 \%$ for males and $20 \%$ for females in Brazil, with little variation over the years and among regions. This percentage, in the year of 2017 , varied from $77.1 \%$ in the North region to $85.4 \%$ in the Midwest. The lowest proportion for males (76.9\%) and highest for females (23.1\%) were recorded in the South region, in 2014. It was also observed that higher proportions for females occurred more frequently in the age group above 13 years $(\mathrm{p}<0.001)$ (Table 3).

Among the professional categories studied, it was observed that the professionals who predominate in the CAPS are the occupational therapist and the clinical psychologist. In addition, there is no record of neuropsychologist information in any type of CAPS. The social psychologist is infrequent, being absent in some types of CAPS and regions. CAPS AD III had fewer professional categories, with the absence of all categories studied in the South and Midwest regions, except for the clinical psychologist, present in the South region (Table 4).

The procedures performed in the CAPS for patients diagnosed with PDD were mostly (63\%) of the type "group patient care" and "individual patient care", while "communicative practices" and psychosocial rehabilitation actions totaled just over $10 \%$ of the total procedures (Table 5). The ratio of total procedures to the number of cases treated, by type of qualification in the period, shows that there is, in general, a ratio of 26.5 procedures / case $(499,547 / 18,852)$. CAPSi presented the second highest ratio, 31.0 procedures / case (427.893 / 13.799), right after CAPS AD III, $66.2(14,101 / 213)$ - data presented in Tables 1 and 5. 


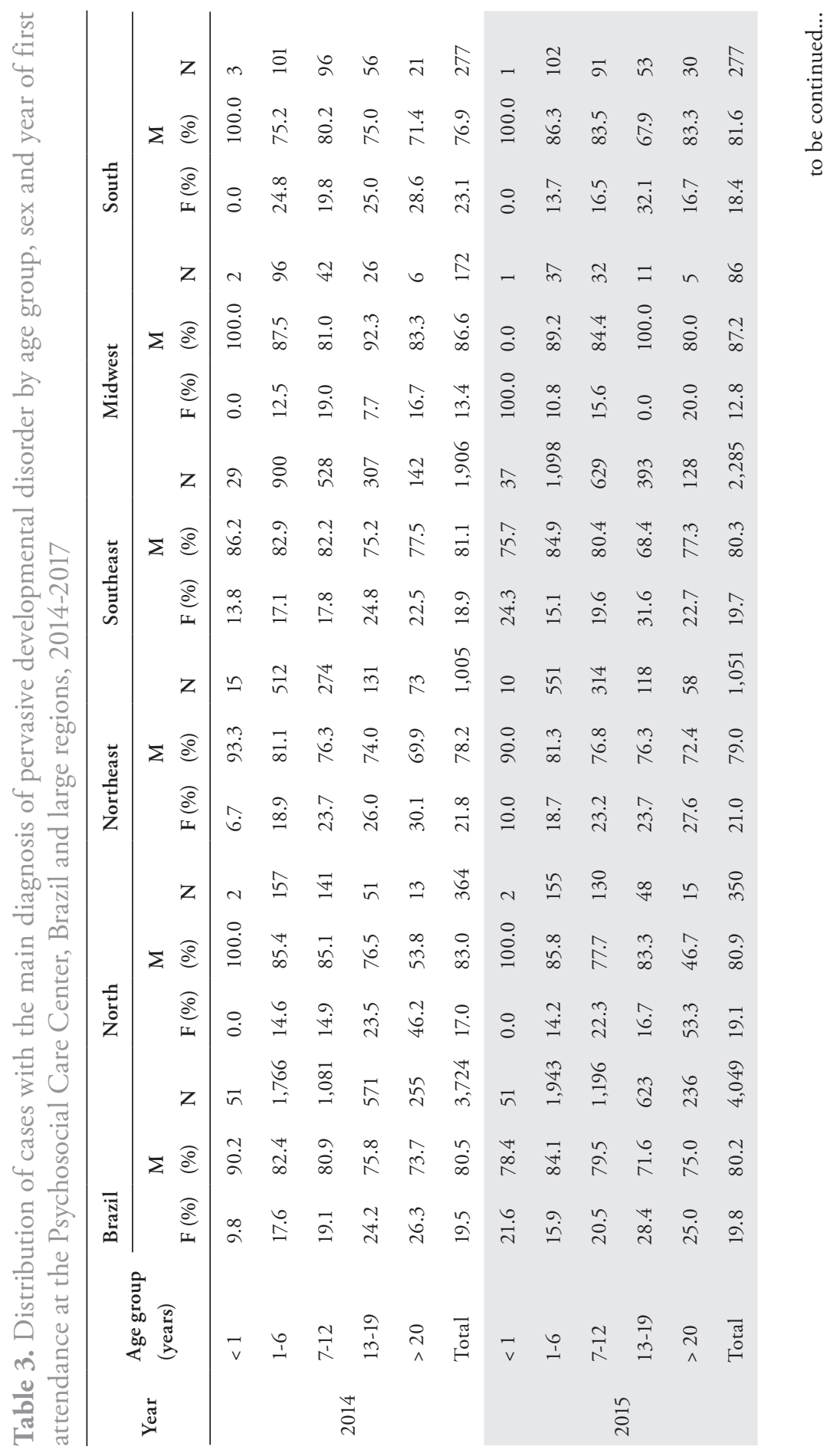




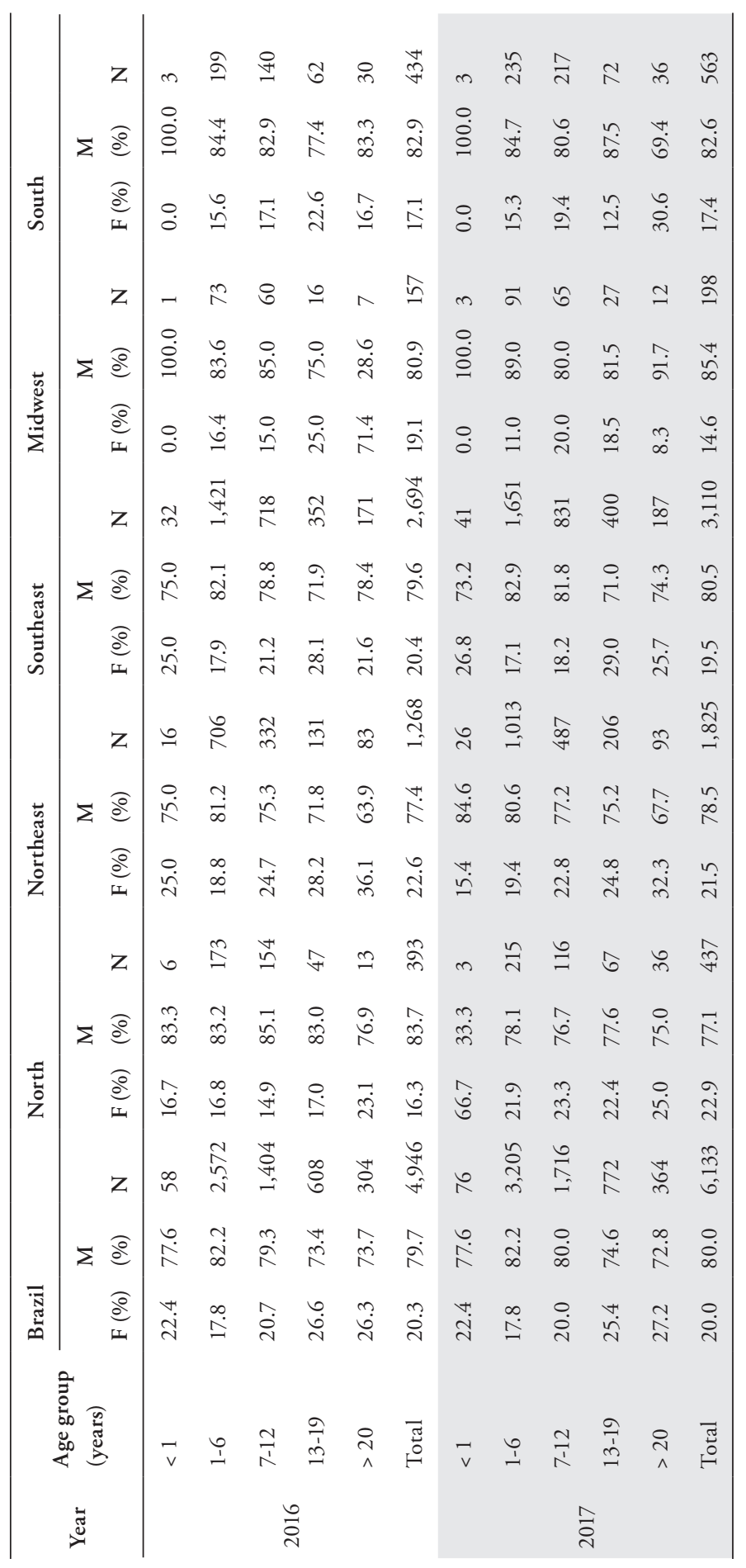




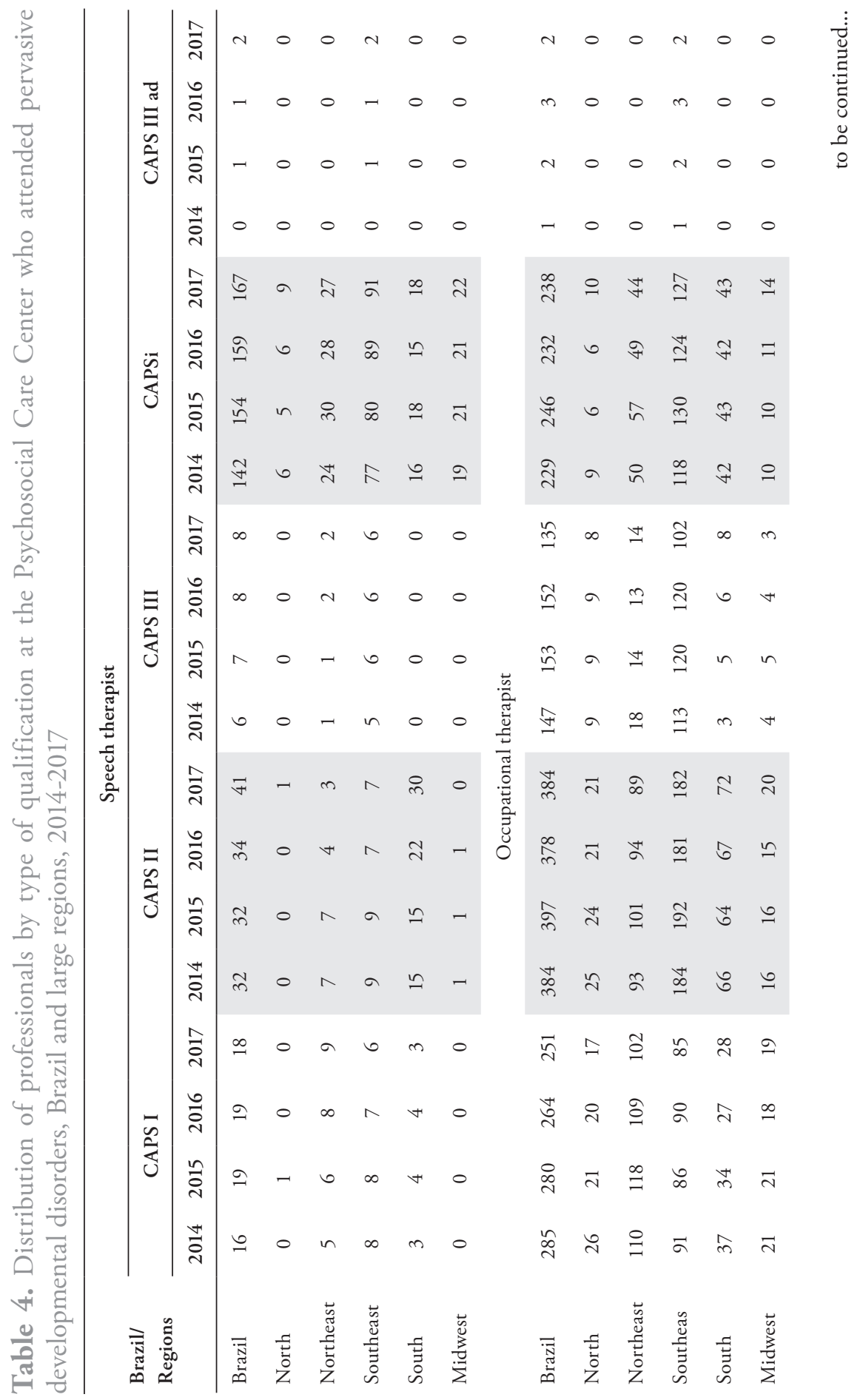




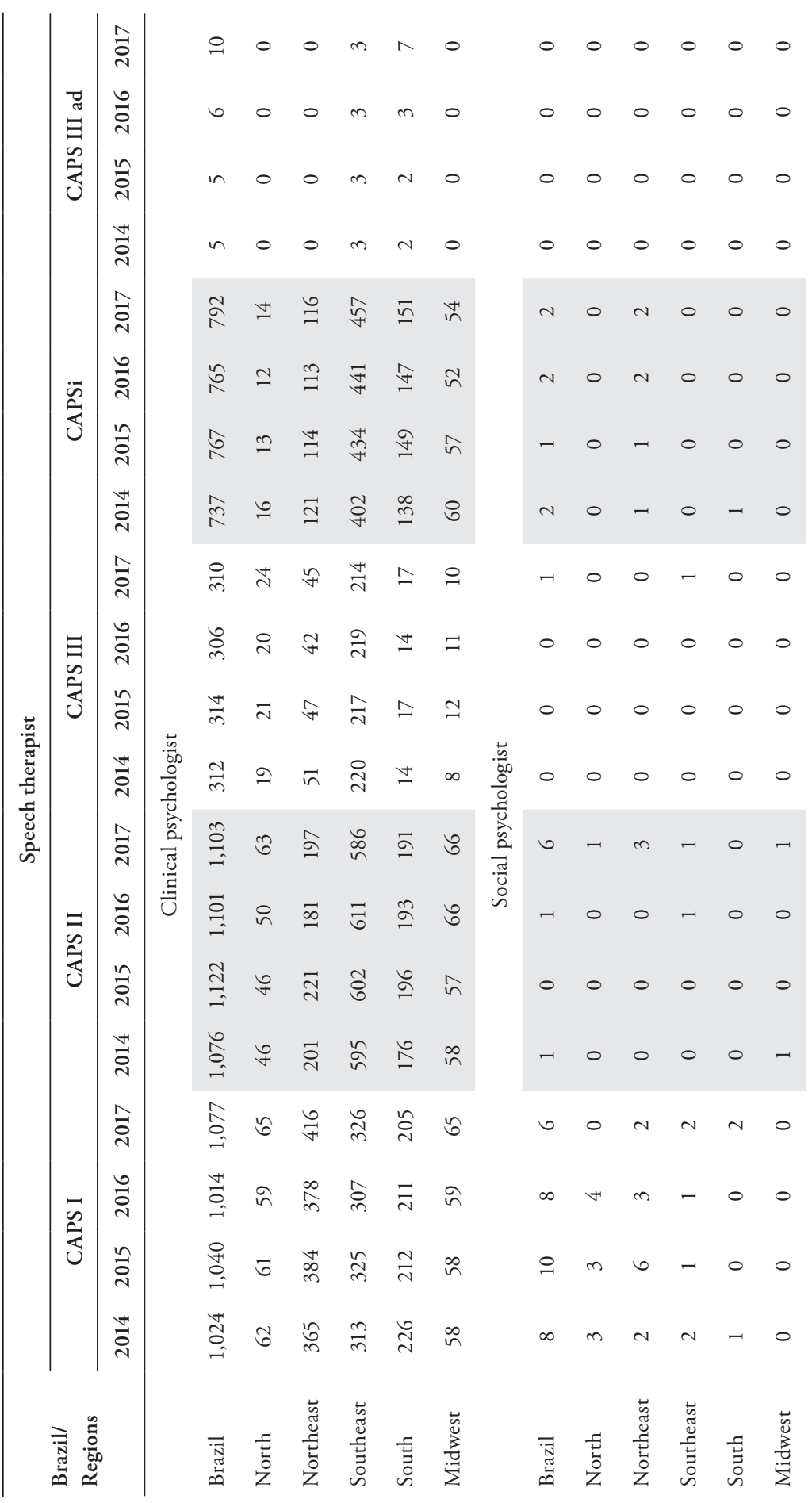




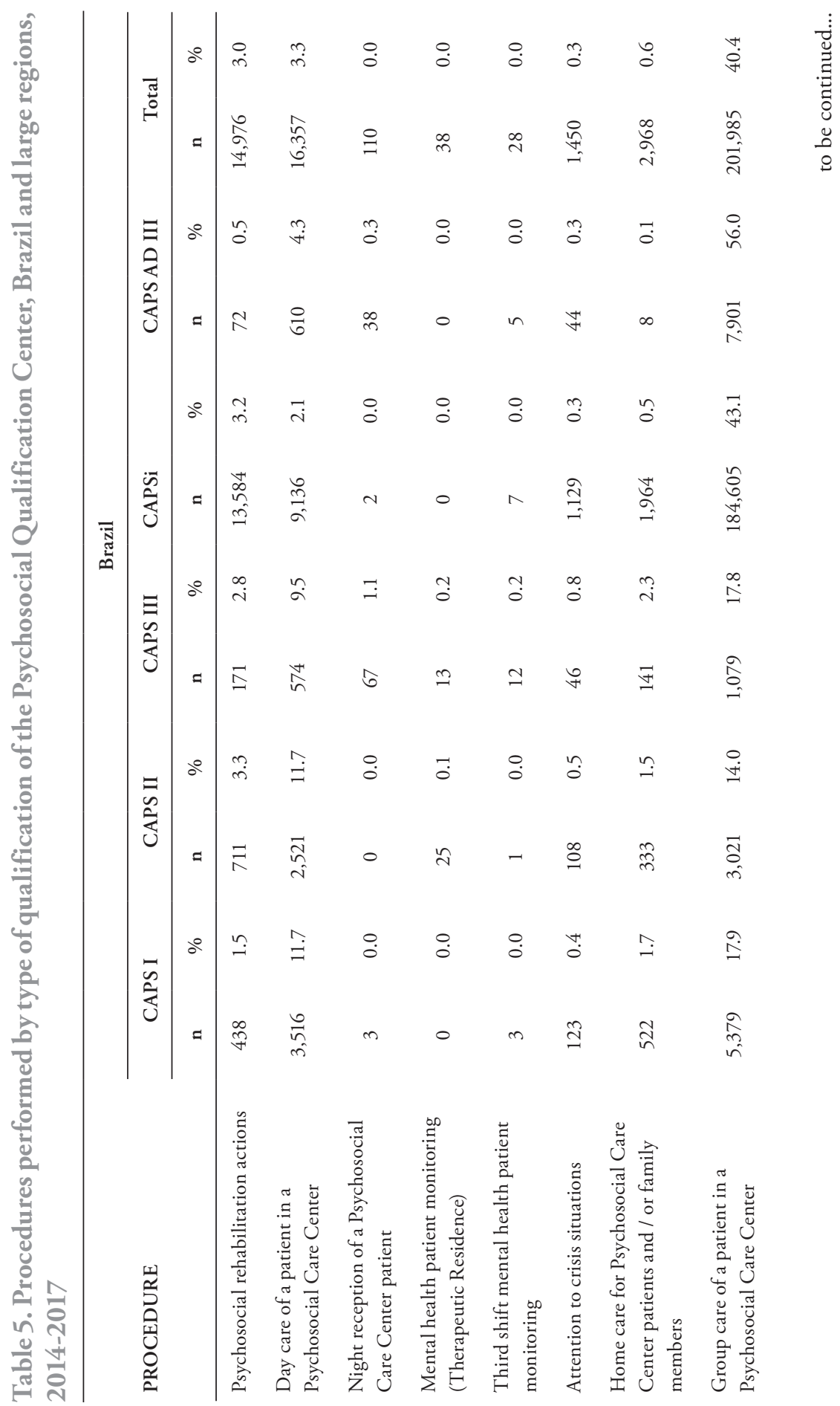




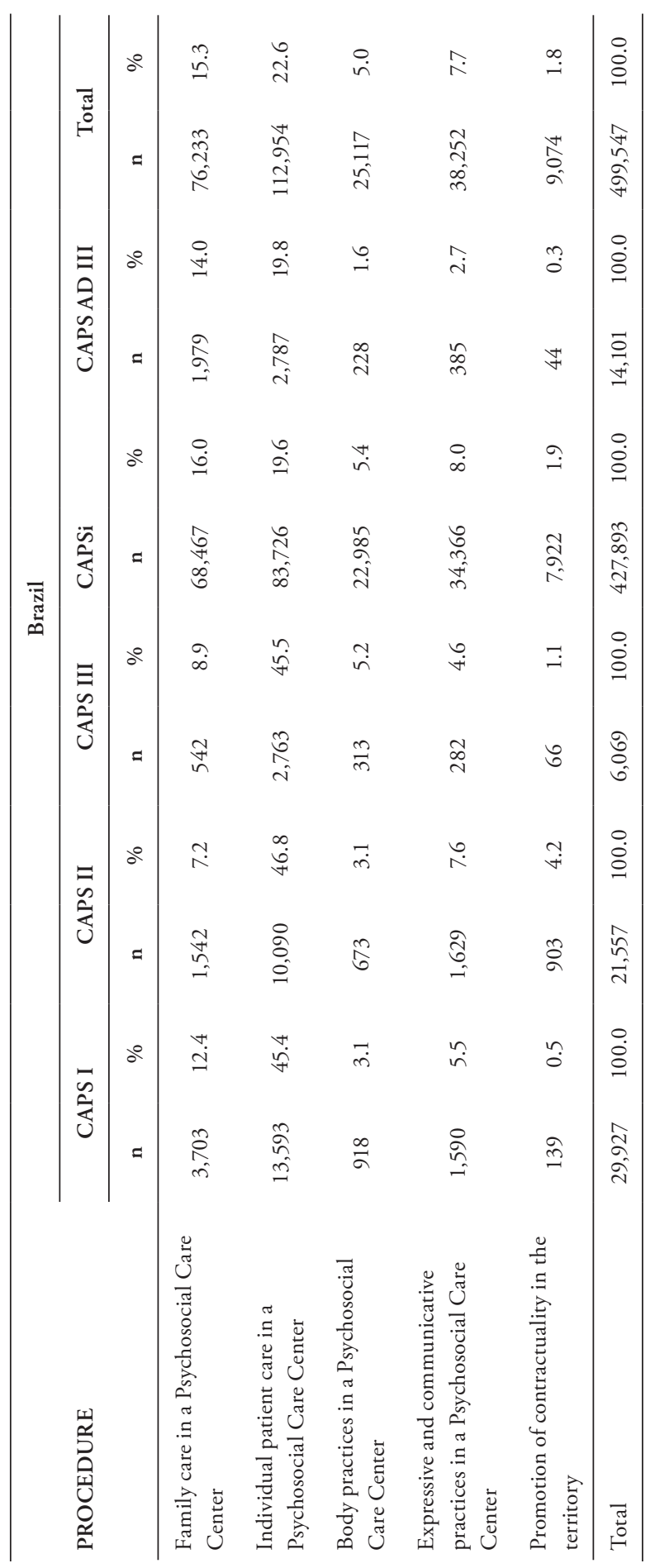




\section{Discussion}

The diagnoses of PDD in CAPS increased over the period evaluated, with a predominance of occurrence in males, which is in accordance with the literature (FOMBONNE, 2009; PAULA et al., 2011b), and in all age groups and regions. Although the study by Ceballos (CEBALLOS et al., 2019) studied the profile of children and adolescents treated at CAPSi from 2008 to 2012, being methodologically different from the present article, which individualized the cases and characterized the treatment of PDD cases in all CAPS, both found a higher proportion in males and an increase in the number of consultations in girls at older ages.

It is noteworthy that the greater number of registered cases does not necessarily imply an increase in the prevalence of these disorders. Several factors have been attributed to the increased prevalence of PDD and ASD, such as access to services, diagnostic criteria and changes over time, method of identifying cases, awareness of the disease, early diagnosis and sample sizes of studies (FOMBONNE, 2009; PAULA et al., 2011a). However, caution is needed when evaluating this increase, given the case definitions and methodologies adopted in the studies (FOMBONNE, 2018). Furthermore, Baxter (BAXTER et al., 2015) comparing the burden estimate of autism and other disorders of the autistic spectrum, following the description of ICD-10 and DSM-IV, for 1990 and 2010, did not find, for both, an increase in prevalence: in 2010 the prevalence of autism was 2.4 per 1,000 and of other spectrum disorders it was 5.1 per 1,000. Elsabbagh and colleagues suggest that estimates of prevalence of ASD have increased over time, with the median around 62 per 10,000 (ELSABBAGH et al., 2012). However, in addition to this study being prior to that of Baxter (BAXTER et al., 2015), there is still the reservation made by the author herself that the observed increase is possibly a reflection of the expansion of the concept of the disorder.

Among PDD diagnoses, autistic disorder was the most frequent. However, more than half of PDD diagnoses have not been classified. The number of PDD diagnoses in children under one year of age is noteworthy. Although the early intervention of diagnosed cases improves the prognosis and the literature points out that it is possible to identify signs of ASD before 12 months (TAMANAHA et al., 2013; OZONOFF et al., 2010; LI et al., 2018; BOSL; TAGER-FLUSBERG; NELSON, 2018), this result may be associated with the quality of the information 
record. The proportion of unclassified PDDs and the proportion of cases in patients younger than 12 months can also signal potential diagnostic errors, a difficulty for the professional to establish the correct diagnosis, as well as a potential problem in care. It is also worth considering the use in the SUS of the ICD-10 classification competing with the practice of DSM-5, which raises relevant questions about the accuracy in the equivalence of classification of disorders and the possible difficulty of the professional in establishing diagnoses.

The proportion of cases between boys and girls found in the country and in the regions follows that reported in the literature, in which this proportion is 4:1 (MAIA et al., 2018; PAULA et al., 2011b; CHRISTENSEN et al., 2016). In boys, the age group with the most frequent diagnosis was 1-6 years old, but with differences when assessed according to the type of CAPS qualification. The study showed that from the age of 13 , in general, female people had a higher proportion of diagnoses compared to younger ages and that the growth trend was significant. This finding points to a possibly later diagnosis for girls and requires more detailed studies. A possible hypothesis for this finding may be a more withdrawn social behavior expected for female children, which in turn would lead to a late diagnosis, during adolescence. The study by Ceballos (CEBALLOS et al., 2019) detected disorders in girls at older ages, but they would tend to present disorders mainly of anxiety and depression. The high proportion of unspecified PDD makes it impossible to know whether the diagnoses "other global and unspecified developmental disorders" could gain more expression.

The high proportion of spontaneous demand for the search for the service found in the study is corroborated in the findings of Felix and Santos (FÉLIX; SANTOS, 2016) and raises questions related to the organization of the care network, since referral from predominantly primary care would be expected. This aspect becomes highly relevant, since an assessment of the person's functionality is necessary to establish the appropriate interventions and the hierarchical level of the SUS service network that addresses this need (TAMANAHA et al., 2013). A possible explanation would be that these children were being diagnosed in a private consultation and would seek continuity of care in the CAPS. This hypothesis, however, needs to be evaluated in new studies. The proportion of patients whose origin was primary care was also expressive, a finding expected considering that this is the main gateway to SUS and the originator of care (BRASIL, 2015). 
The study showed that among the existing professional categories, the most frequent were occupational therapist and the clinical psychologist, and at the CAPSi, also the speech therapist, the latter being important for the differential diagnosis of language disorders. Considering that only CAPS with information on care for children and adolescents diagnosed with PDD were included, the study raises questions about the adequacy of the procedures performed and the sufficiency and diversity of professionals needed for the therapeutic project. Although most PDD patients are seen at CAPSi, 26.8\% are under the care of other types of CAPS, which would not be expected, since they are not specific to children and have a different professional staff. This is a relevant information, considering it is believed that the multi-professional team is important for the most accurate diagnosis (KLIN et al., 2005) and qualifies the entire monitoring of the patient. It is worth noting that professionals are not exclusive to patients with these disorders, and the service is shared with disorders of other nature. The care of children and adolescents with PDD outside of CAPSi may reflect referral problems as well as access logistics between the municipality of residence and the place of care. A mapping of these flows was not foreseen in the study, but it is an analysis that must be explored. The treatment of PDD cases in CAPS AD III and only in the Southeast and South regions is a finding that deserves a local study to elucidate this scenario.

Among the professional specialties, studies are needed to assess whether the clinical focus of the practice includes the scope necessary to evaluate the cognitive functionalities of the PDD and whether the therapeutic plan has been consistent in relation to the procedures reported in the SUS. The treatment interventions used are part of a current evidence-based discussion about which would be most appropriate (LINDGREN; DOOBAY, 2011; DDDMDMH, [S.d.]). Although behavioral-based interventions are pointed out with stronger evidence (LINDGREN; DOOBAY, 2011), it is also pointed out that the lack of methodological rigor in the studies can compromise these analyzes (DDDMDMH, [S.d.]). A study of the Cochrane systematic reviews on ASD interventions showed that they lack quality in evidence, but that even so, reviews with low and very low level of evidence indicate that early behavioral interventions, acupuncture, music therapy, early interventions mediated by parents, groups of social skills and the cognitive model of the theory of mind seem to have some benefit in these patients with the advantage of not being associated with any adverse effect (LYRA et al., 2017). 
The outpatient procedures performed in the CAPS for these patients showed a concentration of "group patient care" and "individual patient care". The low proportion of rehabilitation procedures may be associated with different theoretical concepts that permeate public policy for autism in Brazil, with different care guidelines: the recognition of autism as a mental disorder is inherent in the field of psychosocial care, for example, on the other hand, the concept of autism as a disability leads to a propositional model of treatment through rehabilitation (OLIVEIRA et al., 2017). Thus, the lack of consensus between the design of these models may, in part, explain the low proportion of rehabilitation procedures. However, only an assessment at a local level would make it possible to clarify this scenario, considering that therapeutic methodologies are not established as treatment protocols. It is also worth considering whether the list of procedures described in the SUS procedure table is sufficient for the necessary care for these patients, because, given the scarcity of options, other activities could be launched as group or individual care. Added to this are the interventions pointed out in the Cochrane systematic reviews that are not part of the list of procedures making it impossible to measure whether these practices are carried out in these spaces (LYRA et al., 2017).

The imbalance identified between the professional categories that are in these services may also partially explain the low proportion of some procedures, which may reflect on the therapeutic plan. Despite the recognition of the importance of multidisciplinary work (KLIN et al., 2005; BRASIL, 2014b;, 2015), the absence of explicit criteria and therapeutic methodologies (OLIVEIRA et al., 2017) is possibly reflected in the procedures available in the SUS.

It is worth mentioning that this study is unprecedented because it uses information from the Registry of Outpatient Actions and SCNES to discuss the profile of children and adolescents with pervasive developmental disorder attended at the CAPS, by number of cases, type of CAPS, composition of professional teams and procedures offered. The study also brings the need to discuss care at the CAPS, from the perspective of offering a multi-professional job, and to monitor and evaluate how this is reflected in the procedures reported in the SUS. The lack of specialists in the network, inappropriate conduct regarding the assessment, diagnosis and referral for treatment can be understood as barriers to accessing the child's treatment (FÉLIX; SANTOS, 2016). Finally, it is expected that this study will stimulate the use of the psychosocial care database for study purposes and as support for management. 


\section{Conclusion}

The care of children and adolescents with PDD must be performed at the CAPSi, which includes a multidisciplinary team, which is important to qualify the diagnosis and provide an adequate therapeutic plan. Studies are needed that seek to clarify the reason why some children and adolescents with PDD are being treated in other types of CAPS as well as the predominance of spontaneous demand for these services, the large number of records identified in children under one year old and the reasons for a later diagnosis in female children. The procedures performed point to the need to establish parameters that make it possible to assess whether they are adequate for a therapeutic plan.

Monitoring and evaluating the procedures performed in the CAPS is essential to discuss whether the actions provided are in line with those necessary for the development of autonomy, social reintegration and the rehabilitation of PDD patients. ${ }^{1}$

\section{References}

BAXTER, A. J. et al. The epidemiology and global burden of autism spectrum disorders. Psychological Medicine, v. 45, n. 3, p. 601-613, fev. 2015.

BOSL, W. J.; TAGER-FlusberG, H.; NELSON, C. A. EEG Analytics for Early Detection of Autism Spectrum Disorder: A data-driven approach. Scientific Reports, v. 8, n. 1, dez. 2018. Available at:<http://www.nature.com/articles/s41598-018-24318-x>. Acesso em: 11 fev. 2019.

BRASIL. MINISTÉRIO DA SAÚDE. Portaria 336. Estabelece as modalidades de serviço dos Centros de Atenção Psicossocial, 2002. Available at:<http://bvsms.saude.gov.br/bvs/saudelegis/ gm/2002/prt0336_19_02_2002.html>.

Portaria 3.088. Institui a Rede de Atenção Psicossocial para pessoas com sofrimento ou transtorno mental e com necessidades decorrentes do uso de crack, álcool e outras drogas, no âmbito do Sistema Único de Saúde (SUS), 23 dez. 2011.

Sobre os novos procedimentos de CAPS. [S.l: s.n.]. Available at:<http://portalarquivos. saude.gov.br/images/pdf/2015/janeiro/29/Documento-Sobre-Procedimentos-de-CAPSRAAS-PSI.pdf>, 2013.

Atenção psicossocial a crianças e adolescentes no SUS: tecendo redes para garantir direitos. Brasília: Ministério da Saúde, 2014a. 
Linha de cuidado para a atenção às pessoas com transtornos do espectro do autismo e suas famílias na Rede de Atenção Psicossocial do Sistema Único de Saúde. Brasília: Ministério da Saúde, 2015. Available at:<http://bvsms.saude.gov.br/bvs/publicacoes/linha_cuidado_atencao_ pessoas_transtorno.pdf>.

Diretrizes de Atenção à Reabilitação da Pessoa com Transtornos do Espectro do Autismo (TEA). Brasília: Ministério da Saúde, 2014b.

CEBALlOS, G. Y. et al. Child and Adolescent Psychosocial Care Center service use profile in Brazil: 2008 to 2012. Brazilian Journal of Psychiatry, v. 41, n. 2, p. 138-147, abr. 2019.

CHRISTENSEN, D. L. et al. Prevalence and Characteristics of Autism Spectrum Disorder Among Children Aged 8 Years - Autism and Developmental Disabilities Monitoring Network, 11 Sites, United States, 2012. MMWR. Surveillance Summaries, v. 65, n. 3, p. 1-23, 1 abr. 2016.

DIVISION OF DEVELOPMENTAL DISABILITIES OFTHE MISSOURI DEPARTMENT OF MENTAL HEALTH. Autism Spectrum Disorders: Guide to Evidence-Based Interventions. [S.l.]: Division of Developmental Disabilities of the Missouri Department of Mental Health, [S.d.]. Available at:<https://www.issuelab.org/resource/autism-spectrum-disorders-guide-toevidence-based-interventions.html>.

ELSABbagh, M. et al. Global Prevalence of Autism and Other Pervasive Developmental Disorders: Global epidemiology of autism. Autism Research, v. 5, n. 3, p. 160-179, jun. 2012.

FÉLIX, L. B.; SANTOS, M. F. S. Infância e Atenção Psicossocial. ECOS, v. 6, n. 1, p. 36-50, 2016.

FERREIRA, C. M. B. Nova edição de manual aumenta número de transtornos mentais. Ciência e Cultura, v. 65, n. 4, p. 16-17, 2013.

FOMBONNE, E. Epidemiology of Pervasive Developmental Disorders. Pedriatic Research, v. 65, n. 6, p. 591-598, 2009.

FOMBOnNe, E. Editorial: The rising prevalence of autism. Journal of Child Psychology and Psychiatry, v. 59, n. 7, p. 717-720, jul. 2018.

HAASE, V. G.; JÚLIO-COSTA, A. Como driblar a ilusão dos números? o bom uso de testes neuropsicológicos. In: Compêndio de testes neuropsicológicos: atenção, funçöes executivas e memória. 2a ed. São Paulo: Hogrefe, 2018.

KLIN, A. et al. Clinical evaluation in autism spectrum disorders: psychological assessment within atransdisciplinary framework. In: Volkmar F, Paul R, Klin A, Cohen D,editors. Handbook of Autism and Pervasive Developmental Disorders. 3. ed. New York: Wiley, 2005. v. 2.

KLIN, A. Austismo e Síndrome de Asperger: uma visão geral. Rev Bras Psiquiatr, v. 28, n. Supl I, p. S3-11, 2006. 
LI, G. et al. Early Diagnosis of Autism Disease by Multi-channel CNNs. In: SHI, Y.; SUK, H.-I.; LIU, M. (Org.). Machine Learning in Medical Imaging. Cham: Springer International Publishing, 2018. v. 11046. p. 303-309. Available at:<http://link.springer.com/10.1007/978-3030-00919-9_35>. Acesso em: 11 fev. 2019.

LINDGREN, S.; DOOBAY, A. Evidence-Based Interventions for Autism Spectrum Disorders. . [S.1.]: The University of Iowa, 2011.

LYRA, L. et al. What do Cochrane systematic reviews say about interventions for autism spectrum disorders? Sao Paulo Medical Journal, v. 135, n. 2, p. 192-201, abr. 2017.

MAIA, F. A. et al. Transtorno do espectro do autismo e idade dos genitores: estudo de casocontrole no Brasil. Cadernos de Saúde Pública, v. 34, n. 8, 20 ago. 2018. Available at:<http:// www.scielo.br/scielo.php?script=sci_arttext $\&$ pid $=$ S0102-311X2018000805006\&lng=pt\&tlng= pt>. Acesso em: 21 jun. 2019.

OLIVEIRA, B. D. C. et al. Políticas para o autismo no Brasil: entre a atenção psicossocial e a reabilitação1. Physis: Revista de Saúde Coletiva, v. 27, n. 3, p. 707-726, jul. 2017.

OMS. Cid-10: classificação estatística internacional de doenças e problemas relacionados à saúde. São Paulo: Edusp, 1996.

OZONOFF, S. et al. A Prospective Study of the Emergence of Early Behavioral Signs of Autism. Journal of the American Academy of Child and Adolescent Psychiatry, v. 49, n. 3, p. 256- 66.e1-2, mar. 2010.

PARASMO, B.; LOWENTHAL, R.; PAULA, C. S. Autism spectrum disorders: prevalence and service use in four Brazilian regions. International Conference os Autism in Adult Life: Science, Society and Reality. São Paulo. Archives of Clinical Psychiatry, v. 42, n. Supplement 1, 2015. Available at:<http://docplayer.net/1704074-International-conference-of-autism-in-adultlife-science-society-and-reality-archives-of-revista-de-psiquiatria-clinica.html>.

PAULA, C. F. et al. Conceituação do transtorno do Espectro Autista: definição e epidemiologia. In: Autismo. Avaliação Psicológica e Neuropsicológica. São Paulo: Hogefre, 2017.

PAULA, C. S. et al. Autism in Brazil - perspectives from science and society. Rev Assoc Med Bras, v. 57, n. 1, p. 2-5, 2011a.

PAULA, C. S. et al. Brief Report: Prevalence of Pervasive Developmental Disorder in Brazil: A Pilot Study. Journal of Autism and Developmental Disorders, v. 41, n. 12, p. 1738-1742, dez. 2011 b.

PEDERSEN, A. L. et al. DSM Criteria that Best Differentiate Intellectual Disability from Autism Spectrum Disorder. Child Psychiatry \& Human Development, v. 48, n. 4, p. 537-545, ago. 2017.

R CORE TEAM. A language and environment for statistical computating. n. Vienna, Austria: R Foundation for Statistical Computing, 2013. Available at:<http://www.R-project.org/>. 
ROSNER, B. Fundamentals of biostatistics. 8th edition ed. Boston, MA: Cengage Learning, 2016. SCHMIDT, M. I. et al. Chronic non-communicable diseases in Brazil: burden and current challenges. The Lancet, v. 377, n. 9781, p. 1949-1961, jun. 2011.

TAmanaha, A. C. et al. Protocolo do Estado de São Paulo de Diagnóstico Tratamento e Encaminhamento de Pacientes com Transtorno do Espectro Autista (TEA). São Paulo: SEDPcD, 2013. Available at:<http://www.pessoacomdeficiencia.sp.gov.br)>.

WHO. ICD-XI International Classification of Diseases for Mortality and Morbidity Statistics. [S.1: s.n.], 2018. Available at:<http://www.who.int/classifications/icd/en/>.

YANG, J. et al. Peptidome Analysis Reveals Novel Serum Biomarkers for Children with Autism Spectrum Disorder in China. PROTEOMICS - Clinical Applications, v. 12, n. 5, p. 1700164, set. 2018.

\section{Note}

${ }^{1}$ J.G.Tomazelli participated in the study design, acquisition and analysis of data, writing and critical review of the text. C.S. Fernandes participated in the interpretation of results and critical review of the text. All authors approved the final version, assuming responsibility for all aspects of the work, in order to ensure that issues related to the accuracy or integrity of any part of the work are properly investigated and resolved. 


\section{Resumo}

\section{Centros de Atenção Psicossocial e o}

perfil dos casos com transtorno global do desenvolvimento no Brasil, 2014 - 2017

$\mathrm{O}$ estudo descreve o perfil de crianças e adolescentes com transtorno do desenvolvimento global (TGD) atendidas nos Centros de Atenção Psicossocial (CAPS) e profissionais destes estabelecimentos no Brasil e regiôes. Utiliza dados do Sistema de Informações Ambulatoriais do Sistema Único de Saúde (SIA/SUS) e do Sistema Cadastro Nacional de Estabelecimentos de Saúde (SCNES) de 2014-2017. Relacionou-se deterministicamente as bases SIA/SUS e SCNES, usando o número do estabelecimento, os casos de TGD foram individualizados utilizando a variável cartão SUS codificada. Foram registrados 18.852 diagnósticos de TGD nos CAPS, a maioria por demanda espontânea, $73,2 \%$ realizadas em CAPSi, 50,3\% na faixa etária de 1-6 anos, $80 \%$ do sexo masculino e maiores proporçóes de casos femininos a partir de 13 anos (p<0,001). Em 54,3\% dos diagnósticos não foi especificado o tipo de TGD, sendo o autismo o mais frequente $(27,2 \%)$ dentre os especificados. As equipes profissionais variaram segundo tipo de CAPS. Procedimentos de práticas comunicativas e reabilitação psicossocial foram pouco expressivas (10,3\%). Conclui-se pela necessidade de estudos para esclarecer a alta demanda espontânea, os atendimentos fora do CAPSi e de se estabelecer parâmetros para avaliar se os procedimentos estão adequados ao projeto terapêutico permitindo monitorar e avaliar o atendimento às pessoas com TGD.

> Palavras-chave: Deficiências do Desenvolvimento; Transtorno do Espectro Autista; Serviços de Saúde Mental; Sistema Único de Saúde; Epidemiologia Descritiva. 